DOI: 10.20472/IAC.2018.935.057

\author{
KAMILA ŻYTO
}

Univesity of Łódź, Faculty of Philology, School of Media and Audiovisual Culture, Poland

\title{
NOT ONLY CHILDREN MATTERS - PROBLEMS WITH PRESCHOOL FILM AND MEDIA EDUCATION IN POLAND
}

\begin{abstract}
:
Film and media education in the case of preschool-age-children is a particularly complicated matter. There are many different factors, including the question of methodology, challenges which stem from the learning abilities and skills of young children, that should be discussed. But I will concentrate on institutional deficiencies and social stereotypes connected with preschool film and media literacy and try to indicate the main obstacles audiovisual education in Poland deals with. The question to be asked is: should programmes/institutions dealing with early childhood film and media education and lacking state support focus on children? Or perhaps it is more crucial to address their parents and educators in order to change their attitudes, stereotypical thinking, prejudices or just habits.
\end{abstract}

\section{Keywords:}

film literacy, media literacy,preschool education, sterotypes

JEL Classification: 129 